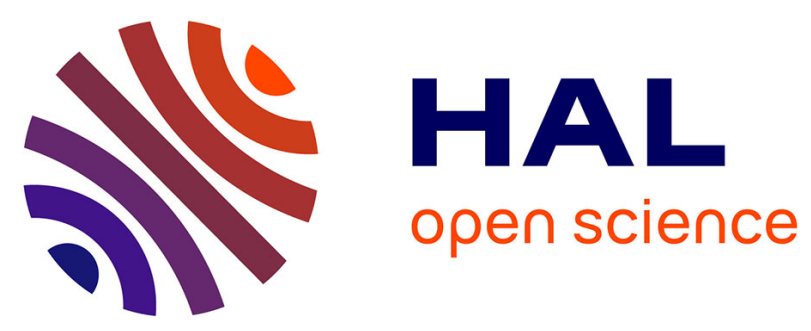

\title{
Biomarker evidence for recent turf cultivation in Northeast Brazil (Lagoa do Boqueirão, RN)
}

Renata Zocatelli, Jérémy Jacob, Bruno Turcq, Mohammed Boussafir, Abdelfettah Sifeddine, Marcelo Bernardes

\section{- To cite this version:}

Renata Zocatelli, Jérémy Jacob, Bruno Turcq, Mohammed Boussafir, Abdelfettah Sifeddine, et al.. Biomarker evidence for recent turf cultivation in Northeast Brazil (Lagoa do Boqueirão, RN). Organic Geochemistry, 2010, 41 (4), pp.427-430. 10.1016/j.orggeochem.2009.12.008 . insu-00445044

\section{HAL Id: insu-00445044 https://hal-insu.archives-ouvertes.fr/insu-00445044}

Submitted on 7 Jan 2010

HAL is a multi-disciplinary open access archive for the deposit and dissemination of scientific research documents, whether they are published or not. The documents may come from teaching and research institutions in France or abroad, or from public or private research centers.
L'archive ouverte pluridisciplinaire HAL, est destinée au dépôt et à la diffusion de documents scientifiques de niveau recherche, publiés ou non, émanant des établissements d'enseignement et de recherche français ou étrangers, des laboratoires publics ou privés. 
Biomarker evidence for recent turf cultivation in Northeast Brazil (Lagoa do Boqueirão, RN)

Zocatelli, R.a,**; Jacob, J.a; Turcq, Bc; Boussafir, M.a; Sifeddine, A.b,c;

Bernardes, M.C. b,c

${ }^{a}$ Institut des Sciences de la Terre d'Orléans, Université d'Orléans/Université François Rabelais de Tours, CNRS/INSU UMR 6113, 1A rue de la Férollerie, 45072 Orléans, France.

${ }^{\mathrm{b}}$ Institut de Recherche pour le Développment (IRD), 32, Avenue Henri Varagnat, 93143 Bondy Cedex, France.

${ }^{c}$ Universidade Federal Fluminense, Morro do Valonguinho s/n, Departamento de Geoquímica, Niterói, Rio de Janeiro, Brasil.

\section{ABSTRACT}

The first meter of sediments in Lagoa do Boqueirão (RN, Brazil) is characterized by low sedimentation rates during the $1000 \mathrm{BC}-1500 \mathrm{AD}$ time period and high sedimentation rate in the top $20 \mathrm{~cm}$, corresponding to the last ten years. Several pentacyclic triterpene methyl ethers (PTME) such as taraxer-14-en-3a-ol ME (crusgallin) and arbor-9(11)-en-36-ol ME (cylindrin) are detected in all sediment samples. The major change in sedimentation rates recorded at $20 \mathrm{~cm}$ is accompanied by a change in PTMEs concentrations and distribution. Sediments deposited during the $1000 \mathrm{BC}-$ 1500 AD time period contain PTMEs at low concentration levels $(1.3 \mu \mathrm{g} / \mathrm{g}$ sed) that could constitute a geochemical background of the grasses that naturally developed in the catchment. High concentrations of PTME are recorded during the 1996-2000 time period. They mainly result from high

\footnotetext{
${ }^{*}$ Corresponding author e-mail address: zocatelli@gmail.com
} 
concentrations of a compound tentatively identified as arbor-8-en-3ßol ME, a potential diagenetic derivative of cylindrin. This increase in PTME corresponds to the beginning of intensive cultivation of Cynodon dactylon and Zoysia japonica (arundoin and cylindrin producers), for the production of turf to cover Brazilian football stadiums and golf practices. These results constitute a novel application of PTMEs to reconstruct land use changes from lake sediment archives.

Key-words: pentacyclic triterpene methyl ethers, land use, turf, lake sediments.

\section{Introduction}

In the last decades land-use changes severely altered soil in tropical countries due to increased demography leading to higher demand for food (Houghton et al., 1991; Houghton, 1994; Ojima et al., 1994; Geissen et al., 2009a) but also for leisure (e.g. turf production). The timing and extent to which these changes in land use affected natural ecosystems, soil quality and biodiversity remain to be evaluated. Lacustrine sedimentary archives can potentially record these modifications if suitable tracers allow discriminating between their natural or anthropogenic causes. Molecular biomarkers have revealed useful to track changes ecosystems (e.g. Fisher et al., 2003; Meyers, 2003; Jacob et al, 2008 a; b). Upon molecular biomarkers, pentacyclic triterpenes constitute a highly diversified family of molecules

that are mostly produced by higher plants (Das and Mahato, 1983; Mahato 
and Sen, 1997). Specifically, pentacyclic triterpenes bearing a methyl ether group at C3 position (pentacyclic triterpene methyl ethers, PTMEs) preserved in lake sediments were shown to be specific of Gramineae (Jacob et al., 2005). One of the first application developed with these compounds was provided by Jacob et al. (2008 a; b) who brought evidence that miliacin (olean-18-en-36-ol methyl ether) preserved in Lake le Bourget sediments (France) originated from broomcorn millet (Panicum miliaceum), an allochthonous plant that was introduced by men in the catchment area of the lake during the Bronze Age. This work proposes another application of PTMEs as biomarkers of grasses to unravel changes in land use and vegetation cover around Lake Boqueirão, northeast Brazil.

\section{Study site}

Lagoa do Boqueirão is a small lake (catchment area of $250 \mathrm{~km}^{2}$ ) located in northeastern Brazil (Rio Grande do Norte State), about $8 \mathrm{~km}$ from the Atlantic coast and close to the equator $\left(5^{\circ} 14^{\prime} 57.1^{\prime \prime} \mathrm{N}, 35^{\circ} 32^{\prime} 42.5^{\prime \prime} \mathrm{O}\right.$, Figure 1). The local climate is tropical semi-humid with pronounced seasonality. Precipitation annually reaches $900 \mathrm{~mm}$ and mostly occurs during the rainy season, from November to May. The mean annual temperature is $26{ }^{\circ} \mathrm{C}$. The

dominant natural vegetation of the region is a grass steppe (restinga). The lake is surrounded by agricultural lands where intensive cultivation of grass is attested by numerous irrigation circles as represented in Figure 1.

\section{Materials and methods}


Core BOQC0701 $(100 \mathrm{~cm})$ was sampled in the centre of the lake with a vibracorer (Martin and Flexor, 1995) and was sliced every $0.7 \mathrm{~cm}$. The samples were dried at $40{ }^{\circ} \mathrm{C}$ in an oven, ground and stored.

\subsection{Extraction and separation of PTMEs}

Lipids were extracted from ca. $0.40 \mathrm{~g}$ of sediment by ASE 200 with dichloromethane:methanol 1:1 v/v. The total extract was fractionated by flash chromatography on activated silica. After the elution of aliphatic and aromatic hydrocarbons, PTMEs were eluted with hexane:toluene (1:1 v/v). Fractions were then dried under $\mathrm{N}_{2}$ and $5 \alpha$ cholestane was added as internal standard before injection.

\subsection{Gas Chromatography-mass spectrometry (GC-MS)}

The fraction containing PTMEs was analyzed by GC-MS with a TRACEPolaris-GCQ. The gas chromatograph was fitted with a Rtx-5MS column (30 $\mathrm{m}, 0.25 \mathrm{~mm}$ i.d., $0.25 \mu \mathrm{m}$ film thickness). The GC operating conditions were: temperature held at $40{ }^{\circ} \mathrm{C}$ for $1 \mathrm{~min}$, then increased from 40 to $120{ }^{\circ} \mathrm{C}$ at $30^{\circ} \mathrm{C} \mathrm{min}$ m $^{-1}, 120$ to $300{ }^{\circ} \mathrm{C}$ at $3{ }^{\circ} \mathrm{C} \min ^{-1}$, with a final isothermal hold at 300 ${ }^{\circ} \mathrm{C}$ over $30 \mathrm{~min}$. The sample was injected splitless, with the injector temperature set at $280{ }^{\circ} \mathrm{C}$. Helium was the carrier gas. The mass spectrometer was operated in the electron ionization (EI) mode at $70 \mathrm{eV}$ ionization energy and scanned from m/z 50 to 600. PTMEs were identified by using standard compounds (Jacob et al., 2005). Due to possible coelutions with other compounds, the PTME concentrations were estimated by 
measuring the areas of their peaks on ion specific chromatograms. PTMEs concentrations were estimated after calculating a correction factor between the peak area on the ion specific chromatogram and the peak area on the Total Ion Current (TIC) on authentic standards.

\section{Results and discussion}

The age model was first established from nine $\mathrm{AMS}{ }^{14} \mathrm{C}$ radiocarbon dates performed on total organic matter at the Laboratoire de Mesure du Carbone 14, Gif sur Yvette, France. These data were calibrated by using the Calib 5.0.2 program (Stuiver, Reimer and Reimer, 2009). Two top-core samples were dated by ${ }^{210} \mathrm{~Pb}$ at the Laboratory of Radioecology and Global Changes (LARAMG) in University of State Rio de Janeiro, Brazil (Table 1).

Lead dating of the upper part of the core $(0$ to $19 \mathrm{~cm})$ indicates a mean sedimentation rate of $1.6 \mathrm{~cm} / \mathrm{yr}$ (Figure 1). Sediments from the bottom core (20 to $100 \mathrm{~cm}$ ) display an average sedimentation rate of $0.033 \mathrm{~cm} / \mathrm{yr}$, estimated from ${ }^{14} \mathrm{C}$ dates. These two distinct sedimentation rates indicate a strong change in sedimentation that happens around $20 \mathrm{~cm}$ depth. This drastic change not only resulted in a large hiatus (estimated between ca. 1500 and 1994) but also in an increase in sediment input.

Ether fractions of sediment extracts contain several PTMEs upon which taraxer-14-en-3bol ME (crusgallin) and arbor-9(11)-en-3bol ME (cylindrin) could be identified with authentic standards (Figure 2). The mass spectrum of compound 1, detected at $44.3 \mathrm{~min}$, is characterized by intense $\mathrm{m} / \mathrm{z} 273$ and $241, \mathrm{M}^{+}$at $440,\left[\mathrm{M}^{+-32}\right]$ at $\mathrm{m} / \mathrm{z} 408,\left[\mathrm{M}^{+-15}\right]$ at $\mathrm{m} / \mathrm{z} 425$ and $\left[\mathrm{M}^{+-32-15}\right]$ at $\mathrm{m} / \mathrm{z}$ 
393, i.e. undistinguishable from the mass spectra of cylindrin, arundoin and related compounds (Jacob et al., 2005). Based on relative retention times between arundoin, fern-8-en-3ßol ME and cylindrin (Ohmoto et al., 1970) with those of our standards and samples (Figure 2), we tentatively attribute an arbor-8-en-3 3 -ol ME structure to compound 1, although it has never been reported yet.

The evolutions of crusgallin and cylindrin concentrations with time are depicted in Figure 3. High concentrations of compound 1 (2.5-11.7 $\mu \mathrm{g} / \mathrm{g}$ sed) are recorded in sediments dated back to the 1996-2000 period whereas the sediments deposited during the 1000 BC-1500 AD are characterized by lower concentrations in compound 1, cylindrin and crusgallin (average 0.1, 0.2 and $0.3 \mu \mathrm{g} / \mathrm{g}$ sed, respectively). PTMEs concentrations found in the lower part of the core could therefore be regarded as the natural background of the grass steppe vegetation.

Compound 1 concentration is on average 20 times higher in the upper part of the core than in the natural background. This increase observed from 1996 to 1999 coincides with the beginning of grass cultivation around Lagoa do Boqueirão in the $90 \mathrm{~s}$, in order to provide turf for soccer, golf and polo fields. Upon the three species cultivated in the area, Cynodon dactylon is reputed to produce arundoin and Zoysia japonica to produce both arundoin and cylindrin (Ohmoto et al., 1970). Since concentrations in cylindrin are below detection level in sediments dated back to the 1996-1999 period, we therefore interpret compound 1 as a probable diagenetic derivative of the 
cylindrin produced by Zoysia japonica. The acidic-catalysed migration leading to $\Delta^{8}$ structures from their $\Delta^{9(11)}$ isomers has been demonstrated for arundoin and for fern-9(11)-en-3ßol (Ageta et al., 1987; Nishimoto et al., 1968). Accordingly, compound 1 could result from the acidic conversion of cylindrin under acidic conditions that presently prevail in the sediment, although this double bond migration has not been demonstrated yet. The higher sensibility of arundoin to acidic conditions (as compared to cylindrin; Nishimoto et al., 1968) could explain the absence of this compound and of its diagenetic derivatives in the sediments from this period.

Sediments dated back to the 2000-2008 period have lower PTMEs concentration than that of natural background and of compound 1 . This drop might result from the withdrawal of most of the natural vegetation cover to create fields for the cultivation of grass as well as intensive agriculture practices (cultivation of coconut, tomato and banana).The decrease in compound 1 concentration around 1996 might result from a better treatment of waste derived from the turf exploitation to the tailings pond.

\section{Conclusion}

The detection and quantitation of grass specific biomarkers in sediments of Lake Boqueirão covering the last 3000 years allowed us to distinguish between natural background and geochemical signature of anthropogenic activities and to unravel recent land use around the lake, in agreement with sedimentary dynamics. A new compound, tentatively identified as arbour-8- 
en-3ßol ME could be a diagenetic derivative of cylindrin produced by Zoysia japonica, a grass cultivated for turf production around the lake.

\section{Acknowledgments}

This work was accomplished as part of a collaboration project between the IRD, the CNPq and ISTO. One of us (R.Z.) received financial support from the CNPq and CAPES. The authors wish to thank the two reviewers for their constructive comments.

\section{References}

Ageta, H., Shiojima, K., Arai Y., 1987. Acid- induced rearrangement of triterpenoids hydrocarbons belonging to the hopane and migrated hopane series. Chemical and Pharmaceutical Bulletin 35, 2705-2716.

Das, M.C., Mahato, S.B., 1983. Triterpenoids. Phytochemistry 22, 10711095.

Fisher, E., Oldfield, F., Wake, R., Boyle, J., Appleby, P., Wolff, G.A., 2003. Molecular marker records of land use change. Organic Geochemistry 34, 105-119.

Geissen, V., Sánchez-Hernández, R., Kampichler, C., Ramos-Reyes, R., Sepulveda-Lozada, A., Ochoa-Goana, S., Jong, B.H.J., Huerta-Lwanga, E., Hernández-Daumas, S., 2009. Effects of land-use change on some properties of tropical soils - An example from Southeast Mexico. Geoderma 151, 87-97. 
Houghton, R.A., 1994. The worldwide extent of land-use change. BioScience 44, 305-313.

Houghton, R.A., Skole, D.L., Lefkowitz, D.S., 1991. Changes in the landscape of Latin America between 1850 and 1985. II. Net release of $\mathrm{CO}_{2}$ to the atmosphere. Forest Ecology and Management 38, 173-199.

Jacob, J., Disnar, J.R., Boussafir, M., Sifeddine, A., Albuquerque, A.L.S., Turcq, B., 2005. Pentacyclic triterpene methyl ethers in recent lacustrine sediments (Lake Caçó, Brazil). Organic Geochemistry 36, 449-461.

Jacob, J., Disnar, J.R., Arnaud, F., Chapron, E., Debret, M., Lallier-Vergès, E., Desmet, M., Revel-Rolland, M., 2008. Millet cultivation history in the French Alps as evidenced by a sedimentary molecule. Journal of Archaeological Science 35, 814-820.

Jacob, J., Disnar, J.R., Bardoux, G. 2008. Carbon isotope evidence for sedimentary miliacin as a tracer of Panicum miliaceum (broomcorn millet). Organic Geochemistry 39, 1077-1080.

Mahato, S.B., Sen, S., 1997. Advances in triterpenoid research 1990-1994. Phytochemistry 44, 1185-1236.

Martin, L., Flexor, J.M., Suguio, K., 1995. Vibrotestemunhador leve. Construção, utilização e potencialidades. Revista IG. São Paulo 16, 5966.

Meyers, P.A., 2003. Applications of organic geochemistry to paleolimnological reconstructions: a summary of examples from the Laurentian Great Lakes. Organic Geochemistry 34, 261-289. 
Nishimoto, K., Ito, M., Natori, S., Ohmoto, T., 1968. The structures of arundoin, cylindrin and fernenols. Triterpenoids of fernane and arborane groups of Imperata cylindrical var. koenigii. Tetrahedron 24, 735-752.

Ojima, D.S., Galvin, K.A., Turner, B.L., 1994. The global impact of land-use change. BioScience 44, 300-304.

Ohmoto, T., Ikuse, M., Natori, S., 1970. Triterpenoids of the Gramineae. Phytochemistry 9, 2137-2148.

Stuiver, M., Reimer, P.J., Reimer, R. 2009. Calib, version 5.02. http://calib.qub.ac.uk/calib/

\section{Table captions}

Table $1:{ }^{14} \mathrm{C}$ dates and ${ }^{210} \mathrm{~Pb}$ data used for the establishment of core BOQC0701 age model.

\begin{tabular}{|c|c|c|c|c|c|}
\hline \multirow[b]{2}{*}{$\begin{array}{l}\text { Laboratory } \\
\text { code }\end{array}$} & \multicolumn{5}{|c|}{${ }^{210} \mathrm{~Pb}$ age information } \\
\hline & $\begin{array}{l}\begin{array}{l}\text { Depth } \\
(\mathrm{cm})\end{array} \\
\end{array}$ & Material dated & $\begin{array}{l}\text { Age } \\
\text { (Yr AD) }\end{array}$ & & $\begin{array}{l}\text { Age } \\
\text { Yrs cal BP }\end{array}$ \\
\hline Boqc0701-1 & 0 & Total organic matter & 2007 & & -1 \\
\hline Boqc0701-2 & 11.2 & Total organic matter & 2000 & & -8 \\
\hline \multirow[b]{2}{*}{$\begin{array}{l}\text { Laboratory } \\
\text { code }\end{array}$} & \multicolumn{5}{|c|}{${ }^{14} \mathrm{C}$ age information } \\
\hline & $\begin{array}{l}\begin{array}{l}\text { Depth } \\
(\mathrm{cm})\end{array} \\
\end{array}$ & Material dated & ${ }^{14} \mathrm{C}$ yr BP & $\begin{array}{l}\delta^{13} \mathrm{C} \\
(\% \circ) \\
\end{array}$ & $\begin{array}{l}\text { Intercept ages } \\
\text { cal yr BP }\end{array}$ \\
\hline SacA 11586 & $21.7-22.4$ & Total organic matter & $660 \pm 30$ & -26.7 & 563 \\
\hline SacA 11587 & $31.5-32.2$ & Total organic matter & $975 \pm 30$ & -26.2 & 804 \\
\hline SacA 11588 & $40.4-40.9$ & Total organic matter & $1660 \pm 30$ & -25.1 & 1425 \\
\hline SacA 11589 & $50.9-51.4$ & Total organic matter & $1645 \pm 30$ & -21.8 & $1422 ; 1455 ; 1518$ \\
\hline SacA 11590 & $59.9-60.4$ & Total organic matter & $1915 \pm 30$ & -23.0 & $1745 ; 1820$ \\
\hline SacA 11591 & $69.9-70.4$ & Total organic matter & $2000 \pm 30$ & -20.7 & 1988 \\
\hline SacA 11592 & 79.9-80.4 & Total organic matter & $2160 \pm 30$ & -24.4 & 2080 \\
\hline SacA 11593 & $90.9-91.4$ & Total organic matter & $2425 \pm 30$ & -24.4 & 2353 \\
\hline SacA 11594 & $99.4-99.9$ & Total organic matter & $2860 \pm 30$ & -26.6 & $2885 ; 2910 ; 2922$ \\
\hline
\end{tabular}


Figure captions

a)

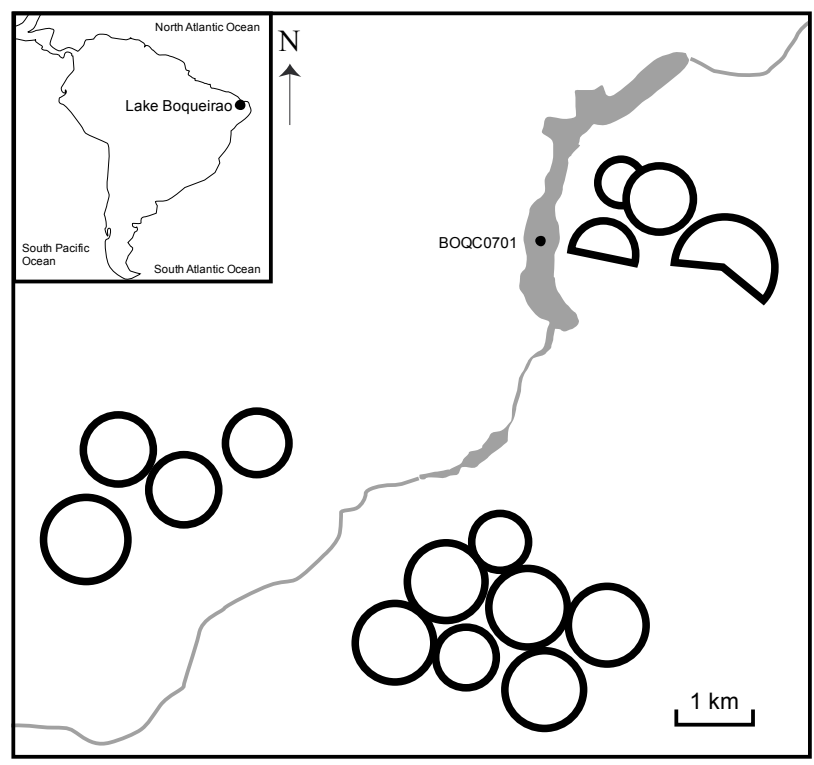

b)

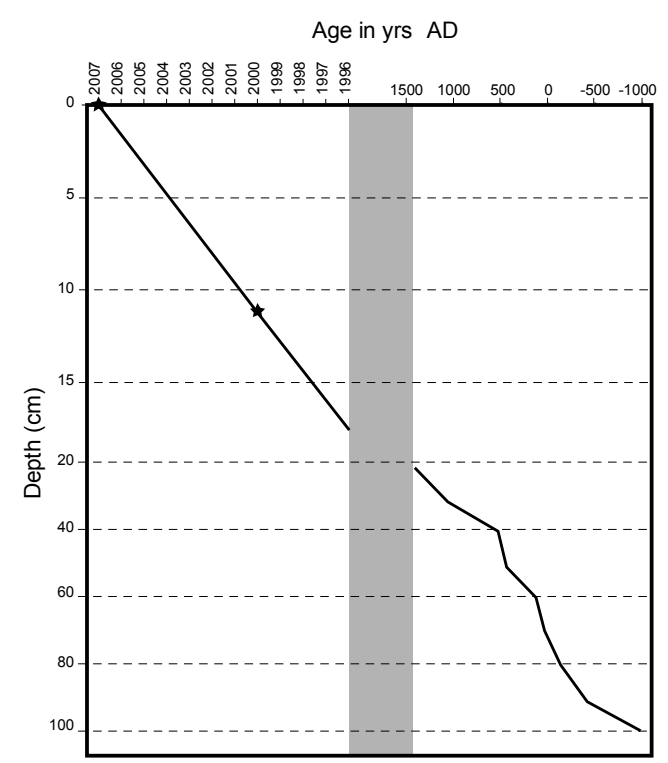

Figure 1: (a) Map of Lake Boqueirão region emphasizing numerous irrigation circles that attest to intensive agriculture in the catchment. The location of core BOQC0701 is indicated by a full circle. (b) Age-depth relationship in core BOQC0701 based on lead and carbon isotopes illustrating the strong change in sedimentation rate at $20 \mathrm{~cm}$. 


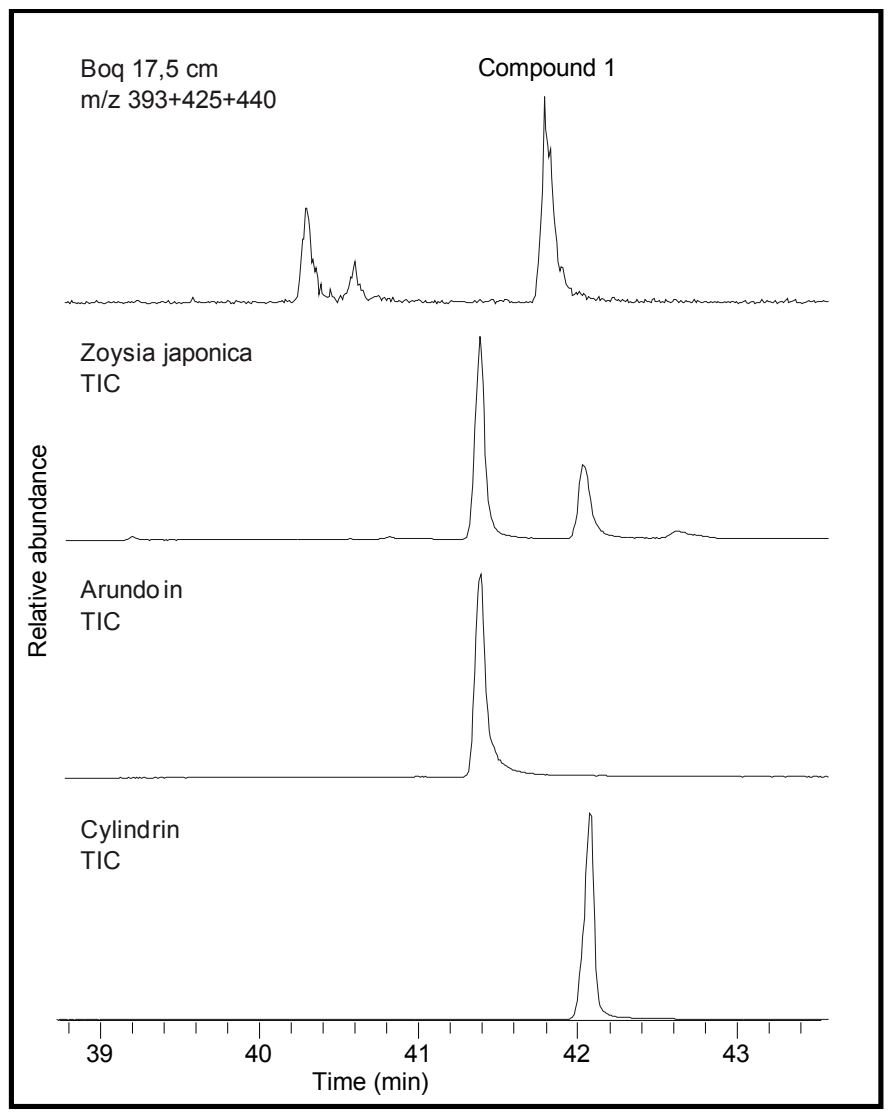

Figure 2: Distribution of PTMEs in the sediments of Lake Boqueirão as illustrated by the partial $\mathrm{m} / \mathrm{z} 393+425+440$ chromatogram of sample collected at $17.5 \mathrm{~cm}$ (upper part of core, $1996 \mathrm{yrs}$ AD) compared to the TIC of Zoysia japonica extract (showing arundoin and cylindrin) and to TIC traces of arundoin and cylindrin standards. 


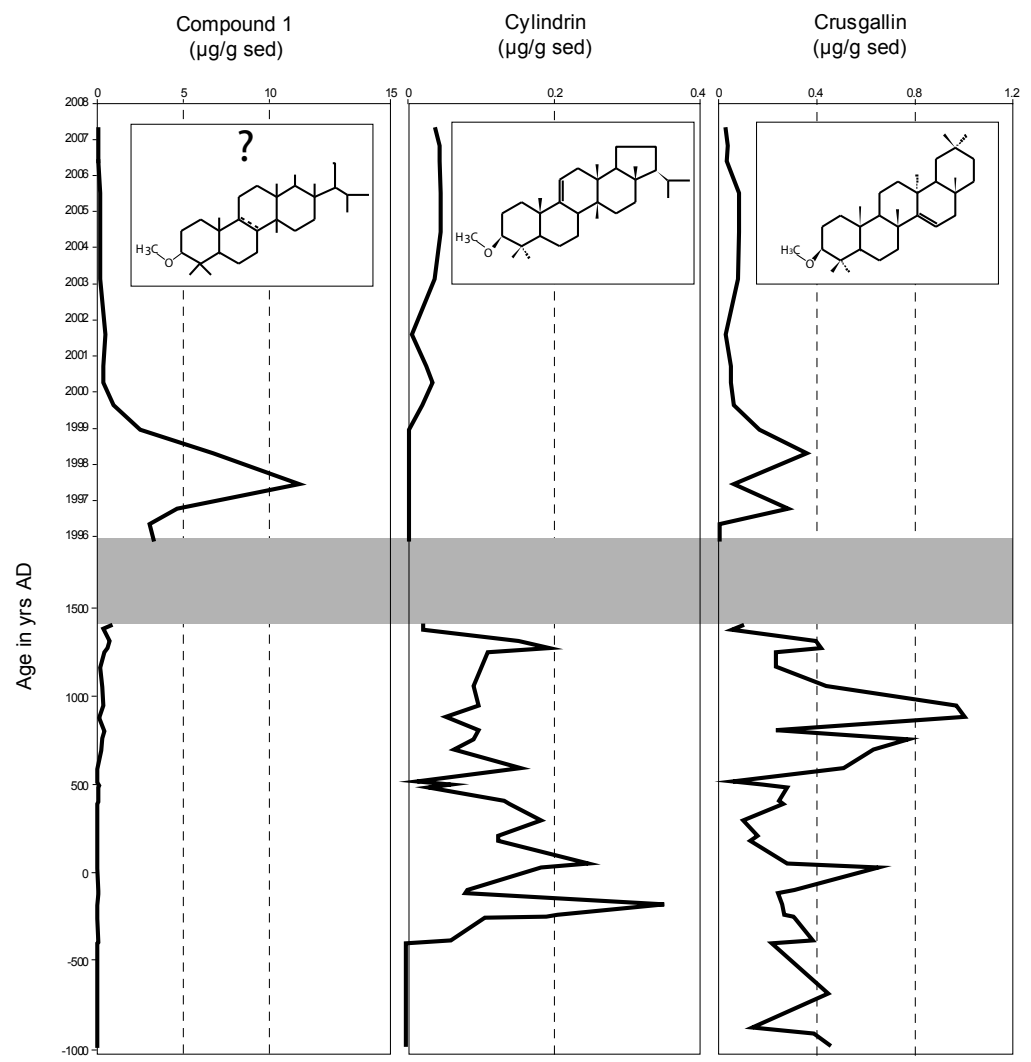

Figure 3: Evolution of compound 1, cylindrin and crusgallin concentrations with time in core BOQC0701. 